\title{
A Simple and Efficient Method for Somatic Embryogenesis and Plant Regeneration from Leaves of Chrysanthemum [Dendranthema $\times$ grandiflorum (Ramat.) Kitamura]
}

\author{
Harue SHINOYAMA ${ }^{1 *}$, Yukio NOMURA ${ }^{1}$ Takao TSUCHIYA ${ }^{2}$ and Toshiharu KAZUMA ${ }^{3}$ \\ ${ }^{1}$ Fukui Agricultural Experiment Station, 52-21 Ryo-machi, Fukui, Fukui 918-8215, Japan \\ ${ }^{2}$ Fukui Agricultural Extension Office, 3-16-10 Matsumoto, Fukui, Fukui 910-8555, Japan \\ ${ }^{3}$ Fukui Prefectural Horticultural Experiment Station, 35-32-1 Kugushi, Mihama, Fukui 919-1123, Japan \\ *Corresponding author E-mail address: harue_shinoyama@fklab.fukui.fukui.jp
}

Received 18 August 2003; accepted 26 September 2003

\begin{abstract}
A simple and efficient method for somatic embryogenesis of chrysanthemum [Dendranthema $\times$ grandiflorum (Ramat.) Kitamura] was established. The best result of somatic embryogenesis was obtained with MS medium containing $2.0 \mathrm{mg} \mathrm{l}^{-1} 2,4$-dichlorophenoxyacetic acid and $1.0 \mathrm{mg} \mathrm{l}^{-1}$ kinetin. Embryos with roots 1 to $2 \mathrm{~mm}$ long gave the highest frequency for conversion of embryos to plantlets. Root meristems appeared to be formed in somatic embryos by 20 days after culture initiation, while the shoot apices formed after replanting in phytohormone-free medium, resulting in a bipolar structure. The embryo-specific ECP63 gene was expressed in the somatic embryos, as in zygotic embryos, confirming that the plant regeneration occurred via embryogenesis. The growth habits and leaf and flower morphology of the regenerated plantlets were normal, but the day of flowering differed from that of cutting controls. The present somatic embryogenesis method was applicable to 8 out of 13 cultivars studied.
\end{abstract}

Key words: chrysanthemum, leaf segment, phytohormone, somatic embryo.

\section{Abbreviations}

2,4-D, 2,4-dichlorophenoxyacetic acid; BAP, 6benzylaminopurine; ECP63, embryogenic cell protein 63 ; FAA, formalin acetic acid; $\mathrm{GA}_{3}$, gibberellic acid $A 3$; 2iP, 2-iso pentenyl adenine; Kin, kinetin; SEM, scanning electron microscope.

\section{Introduction}

Chrysanthemum [Dendranthema $\times$ grandiflorum (Ramat.) Kitamura] was introduced to Japan from China during the Nara Era (A.D. 710-794), and now it is one of the most important ornamental plants. Seedlings for commercial production are obtained by vegetative propagation of stem cuttings. In vitro propagation via adventitious shoot formation from various tissues and organs is also possible (Hill, 1968; Iizuka et al., 1973; Earle and Langhans, 1974; Khalid et al., 1989). Tissue culture methods provide means to eliminate various pathogens (Ahmed et al., 1987; Horst, 1990) and to induce and select desirable mutations (Broertjes et al., 1976; Preil et al., 1983; De Jong and Custers, 1986; Dalsou and Short, 1987; Huitema et al., 1987).

Steward et al. (1958) and Reinert (1958) first recognized somatic embryogenesis in plants. They reported that somatic cells of carrot cultured in vitro formed somatic embryos. Somatic embryogenesis has since been extensively investigated as a model system for understanding the mechanism of zygotic embryogenesis, because the morphological changes in somatic embryos are similar to those in zygotic embryos. Somatic embryogenesis has been reported in several plant species, including chrysanthemum (Earle and Langhans, 1974; May and Trigiano, 1991; Pavingerova et al., 1994), coffee (Nakamura et al., 1994), potato (De Garcia and Martinez, 1995), melon (Tabei et al., 1991), carnation (Frey et al., 1992), alfalfa (Xu and Bewley, 1992), cucumber (Lou and Kako, 1995), and sunflower (Krasnyanski and Menczel, 1993). Somatic embryogenesis is an in vitro process for plant regeneration that is potentially a very efficient system for the clonal mass propagation of plants (Sharp et al., 1982; Lutz et al., 
1984; Ammirato and Styer, 1985). In addition, somatic embryos are generally thought to arise from a single cell (Nomura and Komamine, 1985), so this technique should be useful for the dissolution of chimeras in mutation breeding and gene recombination breeding.

Somatic embryogenesis is induced by transferring somatic tissue cultured on a medium containing 2,4 -di-cholorophenoxyacetic acid (2,4-D) to 2,4-Dfree medium. 2,4-D is a strong herbicide that is thought to be a stress agent in producing somatic embryogenesis (Kato and Takeuchi, 1966; Nomura and Komamine, 1985; Zimmerman, 1993). Alternatively, somatic embryos of carrot can also be induced by treating apical shoot tips with osmotic stress such as high concentrations of sucrose (Kamada et al., 1989, 1993), $\mathrm{NaCl}$ (Kiyosue et al., 1989) and heavy metal ions (Kiyosue et al., 1990), or heat stress (Kamada et al., 1994) in phytohormone-free medium. By these methods, somatic embryos are formed directly on the surface of plant segments, without visible callus formation, after the segments have been subcultured in phytohormonefree medium without these chemicals or at high temperature. Nomura and Komamine (1985) and Zimmerman (1993) suggested that 2,4-D would trigger the induction of somatic embryogenesis, which is not formed by the other chemicals or high temperature, by forming some suitable substance. This substance is believed to induce many physiological changes in segments before and after treatments that are not directly involved in somatic embryogenesis.

Somatic embryogenesis in chrysanthemum has been reported (Earle and Langhans, 1974; May and Trigiano, 1991; Pavingerova et al., 1994). Earle and Langhans (1974) noted that 'embryoids' were formed in callus cultures of Chrysanthemum morifolium Ramat. (Dendranthema $\times$ grandiflorum), but did not present substantial evidence. The other two papers noted that a 'somatic embryo' was formed directly from leaf segments on MS basal medium containing 2,4-D and 6-benzylaminopurine (BAP), or 2,4-D, BAP, 2-iso pentenyl adenine (2iP), and gibberellic acid A3 $\left(\mathrm{GA}_{3}\right)$. Unfortunately, the frequency of plant regeneration from somatic embryos using those protocols is low and highly dependent on the genotype. Furthermore, the procedures are complicated and time-consuming, as they require several regular changes of the medium and in the culture conditions. In addition, detailed data warranting that plants regenerate from the somatic embryos are lacking.

This study developed a method for plant regeneration via somatic embryogenesis in chrysan- themum that is simple, efficient and independent of genotype. We succeeded in establishing the method in the cv. Shuho-no-chikara and other major Japanese cultivars. We also confirmed that plants were regenerated from somatic embryos, based on histological observations and by the expression of an embryo-specific gene.

\section{Materials and Methods}

\section{Plant materials}

The chrysanthemum [Dendranthema $\times$ grandiflorum (Ramat.) Kitamura] cv. 'Shuho-no-chikara' and 12 other cultivars were used. Plants growing in a greenhouse were surface-sterilized in $70 \%$ ethanol, and then in $1 \%$ sodium hypochlorite solution for $15 \mathrm{~min}$, before being rinsed three times with sterile distilled water. In vitro cultures were established from meristem cultures on Murashige and Skoog (1962) basal medium (MS medium) containing 3\% sucrose and $0.3 \%$ Gellan Gum (Pure Chemical, Inc. Kyoto). The medium was adjusted to $\mathrm{pH} 5.8$ before autoclaving at $121^{\circ} \mathrm{C}$ for $15 \mathrm{~min}$. The in vitro culture was maintained at $25^{\circ} \mathrm{C}$ under a $16-\mathrm{h}$ photoperiod using cool-white fluorescent lamps and $25^{\circ} \mathrm{C}$ darkness for $8 \mathrm{~h}$. The lamps provided a photosynthetic photon flux [PPF (400-700 nm)] of $30 \mu \mathrm{mol} \mathrm{m}^{-2} \mathrm{~s}^{-1}$.

\section{Optimizing the phytohormones for somatic embry-} ogenesis

We used three phytohormones: 2,4-D, kinetin (Kin), and BAP. To optimize the conditions for somatic embryogenesis from leaves, combinations of these phytohormones were examined. The MS medium was supplemented with $1.0,2.0$, or 4.0 $\mathrm{mg} \mathrm{l}^{-1} 2,4-\mathrm{D}$ in factorial combination with $0,0.1$, $0.5,1.0$, or $2.0 \mathrm{mg} \mathrm{l}^{-1} \mathrm{Kin}$ or BAP, and used to test for the formation of somatic embryo. One- to 1.2$\mathrm{cm}$ long young leaves were excised from plants and cut into $3 \times 3-\mathrm{mm}$ segments, excluding the distal and basal portions of the lamina. Nine segments were placed with the abaxial surface in contact with the above mentioned medium, and the segments were then incubated under a $16-\mathrm{h}$ photoperiod with cool - white fluorescent lamps that provided a photosynthetic photon flux [PPF (400-700 nm)] of $15 \mu \mathrm{mol}$ $\mathrm{m}^{-2} \mathrm{~s}^{-1}$. We counted the number of somatic embryos in each segment. This procedure was repeated three times.

\section{Plantlet regeneration from somatic embryos}

Shoots at several stages were used; globular stage (root length $0 \mathrm{~mm}$ ), oval stage (1 to $2 \mathrm{~mm}$ ), early elongated root stage ( 3 to $6 \mathrm{~mm}$ ), and late elongated 
root stages ( 7 to 10,11 to 15,16 to 20 , and over 20 $\mathrm{mm})$. They were transferred to phytohormone-free MS medium, and the number of shoots that regenerated plantlets was counted.

\section{Histological observation of somatic embryos}

The segments with somatic embryos were fixed in formalin acetic acid (FAA), dehydrated in a graduated ethanol concentrations of 50,70,85, 95, and $100 \%$ by volume, and then transferred to $n$-butyl alcohol. The time of immersion in each solution was $1 \mathrm{~h}$. After this process, they were embedded in paraffin (Merck Co. Germany). Serial of $10-\mu \mathrm{m}$ sections obtained with a JUNG RM2045 (Leica, Germany) were double-stained with Delafield's hematoxylin solution and eosin-acetic acid solution.

\section{Scanning electron microscopy}

Somatic embryos at different stages were fixed in FAA. Samples were dehydrated in graduated ethanol concentrations of $50,60,70,80,90,99.5$, and $100 \%$ by volume. The time of immersion in each ethanol solution was $1 \mathrm{~h}$. Ethanol was then replaced by 3 -methylbutyl acetate for $15 \mathrm{~min}$ for dehydration. This procedure was repeated twice. The solvent exchanged with liquid $\mathrm{CO}_{2}$, and the samples were critical-point dried. Sections were coated with gold-palladium on a Quick Cool Coater SC701MCY (Sanyu-Denshi, Japan) and examined using a JSM-5410LV scanning electron microscope (JOEL, Japan) (Xu and Bewley, 1992).

\section{Northern blot analysis of ECP63 expression}

In order to investigate whether the regeneration observed here was embryogenesis, a cDNA clone containing the full length of ECP 63 gene isolated by Zhu et al. (1996) was used. This gene encodes embryogenic cell protein 63 (ECP63) of carrot (Daucus carota L.), which specifically exists in embryogenic cells and somatic embryos, and responds to ABA only in embryonic organs. Total RNA was extracted from $100 \mathrm{mg}$ of fresh somatic embryos, leaves, petals, and zygotic embryos of cvs. Shuho-no-chikara and Yamate-shiro. The materials were homogenized in liquid nitrogen using a ceramic mortar and pestle, and extracted using a Qiagen RNeasy Plant Total RNA Kit (Qiagen, USA). Twenty micrograms of RNA were fractionated by formaldehyde gel electrophoresis through $0.8 \%$ agarose and ethidium bromide in MOPS buffer (20 mM MOPS, $5 \mathrm{mM}$ sodium acetate, $1 \mathrm{mM}$ EDTA, pH 7.0). Equal loading was verified by the ethidium bromide-staining. The gel was then blotted onto a positively-charged nylon membrane (Roche \& Boehringer Mannheim, Germany). The pre-hybridization, hybridization, and detection conditions were made as described by Southern (1975). Total RNA was isolated from each shoot using the guanidinium thiocyanate protocol described previously (Newman et al., 1993) using a 520-bp DIG-labeled cDNA (313 to 833 bp) that corresponds to ECP63 gene (Zhu et al., 1996) provided by Prof. H. Kamada, University of Tsukuba.

\section{Morphological observation of regenerated plants in a greenhouse}

The regenerated plantlets were planted into a cell tray with vermiculite and covered with a plastic sheet for acclimation in the greenhouse at $25^{\circ} \mathrm{C}$. After 2 weeks, the plantlets were repotted in soil and grown in the greenhouse. On flowering, about six months after acclimation, we evaluated stem length, number of leaves, diameter of flower and days to flowering.

\section{Results}

Optimizing the phytohormone combinations for somatic embryogenesis

The color of leaf segments turned yellow 2 to 3 days after culture initiation. A white to pale yellow primary callus was formed along the cut edges of the segments and the subepidermal parts by 5 to 7 days of the culture. Somatic embryogenesis was observed on the medium containing a combination of 2,4-D and BAP or Kin, but not on the medium with 2,4-D alone (Table 1). Kin appeared to be more effective than BAP. The number of somatic embryos increased linearly with the Kin concentration from 0.1 to $1.0 \mathrm{mg} \mathrm{l}^{-1}$. Embryogenesis was inhibited at $2.0 \mathrm{mg} \mathrm{l}^{-1} \mathrm{Kin}$. The highest yield of somatic embryos was obtained on the medium containing $2.0 \mathrm{mg} \mathrm{l}^{-1} 2,4-\mathrm{D}$ and $1.0 \mathrm{mg} \mathrm{l}^{-1} \mathrm{Kin}$. This medium is designated hereafter $\mathrm{D} 2 \mathrm{~K} 1$ medium (see Table 1).

Observing somatic embryo and plantlet development

Globular somatic embryos were observed 14 to 21 days after initiation of the culture on $\mathrm{D} 2 \mathrm{~K} 1$ medium (Fig. 1A-C). At this stage, the root meristem and vascular bundles had already formed. When these somatic embryos were transferred to phytohormone - free MS medium (Fig. 1D), they formed shoot and root meristems, obtained morphological bipolarity after 10 days (Fig. 1E), and regenerated into plantlets after 20 days (Fig. 1F). Twenty-eight days after the initiation of culture on D2K1 medium, the roots of somatic embryos continued to grow (Fig. 
Table 1 Effects phytohormone combinations on induction of somatic embryos in chrysanthemum cv. Shuho-no- chikara.

\begin{tabular}{|c|c|c|c|c|c|}
\hline \multirow[b]{2}{*}{ Medium code } & \multicolumn{3}{|c|}{ Additional substances } & \multirow[b]{2}{*}{ Callus formation } & \multirow{2}{*}{$\begin{array}{l}\text { No. of somatic embryo } \\
\text { per leaf segment }\end{array}$} \\
\hline & $\begin{array}{l}2.4-\mathrm{D} \\
\left(\mathrm{mg} \mathrm{l}^{-1}\right)\end{array}$ & $\begin{array}{c}\text { BAP } \\
\left(\mathrm{mg} \mathrm{l}^{-1}\right)\end{array}$ & $\begin{array}{c}\text { Kin } \\
\left(\mathrm{mg} \mathrm{l}^{-1}\right)\end{array}$ & & \\
\hline Control & 0.0 & 0.0 & 0.0 & - & - \\
\hline D1 & 1.0 & 0.0 & - & \pm & $0.0 \pm 0.0$ \\
\hline D1B01 & 1.0 & 0.1 & - & + & $0.8 \pm 1.2$ \\
\hline D1B05 & 1.0 & 0.5 & - & + & $1.2 \pm 2.1$ \\
\hline D1B1 & 1.0 & 1.0 & - & ++ & $2.0 \pm 1.6$ \\
\hline D1B2 & 1.0 & 2.0 & - & + & $2.3 \pm 1.3$ \\
\hline D1K01 & 1.0 & - & 0.1 & + & $5.2 \pm 0.2$ \\
\hline D1K05 & 1.0 & - & 0.5 & + & $4.4 \pm 0.4$ \\
\hline D1K1 & 1.0 & - & 1.0 & ++ & $6.0 \pm 0.6$ \\
\hline $\mathrm{D} 1 \mathrm{~K} 2$ & 1.0 & - & 2.0 & ++ & $3.7 \pm 0.4$ \\
\hline D2 & 2.0 & 0.0 & - & \pm & $0.0 \pm 0.0$ \\
\hline D2B01 & 2.0 & 0.1 & - & + & $0.5 \pm 1.2$ \\
\hline D2B05 & 2.0 & 0.5 & - & + & $3.2 \pm 2.2$ \\
\hline D2B1 & 2.0 & 1.0 & - & + & $4.8 \pm 1.6$ \\
\hline $\mathrm{D} 2 \mathrm{~B} 2$ & 2.0 & 2.0 & - & ++ & $3.1 \pm 1.7$ \\
\hline $\mathrm{D} 2 \mathrm{~K} 01$ & 2.0 & - & 0.1 & + & $4.8 \pm 0.5$ \\
\hline D2K05 & 2.0 & - & 0.5 & + & $10.0 \pm 1.2$ \\
\hline $\mathrm{D} 2 \mathrm{~K} 1$ & 2.0 & - & 1.0 & + & $21.3 \pm 1.2$ \\
\hline $\mathrm{D} 2 \mathrm{~K} 2$ & 2.0 & - & 2.0 & ++ & $6.0 \pm 1.8$ \\
\hline D4 & 4.0 & 0.0 & - & \pm & $0.0 \pm 0.0$ \\
\hline D4B01 & 4.0 & 0.1 & - & + & $0.0 \pm 0.0$ \\
\hline D4B05 & 4.0 & 0.5 & - & + & $0.0 \pm 0.0$ \\
\hline D4B1 & 4.0 & 1.0 & - & + & $0.0 \pm 0.0$ \\
\hline $\mathrm{D} 4 \mathrm{~B} 2$ & 4.0 & 2.0 & - & + & $0.1 \pm 0.6$ \\
\hline D4K01 & 4.0 & - & 0.1 & + & $2.2 \pm 0.5$ \\
\hline D4K05 & 4.0 & - & 0.5 & + & $7.6 \pm 0.6$ \\
\hline D4K1 & 4.0 & - & 1.0 & + & $4.2 \pm 0.9$ \\
\hline D4K2 & 4.0 & - & 2.0 & + & $2.9 \pm 1.8$ \\
\hline
\end{tabular}

Nine leaf segments were put onto each Petri dish.

Data represent mean \pm SE of 27 samples.

1G). These shoots were easily detached from the segment with forceps, whereas adventitious shoots and roots had to be cut off with a scalpel. This difference was a good way to distinguish somatic embryos from adventitious shoots and roots. After being subcultured in phytohormone-free MS basal medium, shoots were formed on the apex of the somatic embryos and the roots were allowed to continue to grow (Fig. 1H-L). The somatic embryos developed into plantlets on D2K1 medium 40 to 50 days after culture initiation (Fig. 1M, N), but the frequency of plant regeneration was very low. Somatic embryos with roots of different lengths were transferred to phytohormone-free medium and the number of somatic embryos that developed into plantlets was counted (Table 2). Somatic embryos at the oval stage (1 to $2 \mathrm{~mm}$ root length) had the highest frequency of plant regeneration. Conversely, the rate was very low for somatic embryos at the later root elongation stages (up to $7 \mathrm{~mm}$ ) or those that were not transferred to phytohormone-free MS medium.

\section{Northern blot analysis of ECP63}

Total RNA was extracted from somatic embryos of cvs. 'Shuho-no-chikara', 'Monroe', 'Symbol', 'Kin-fusya', and 'Hiroshima-beni', and from other tissues, including leaves and petals of 'Shuho-nochikara' and zygotic embryos of 'Shuho-no-chikara' $x^{\prime}$ Yamate-shiro', and subjected to Northern blot analysis. With the specific 520 -bp probe encoding ECP63 gene (Fig. 2), the somatic and zygotic 

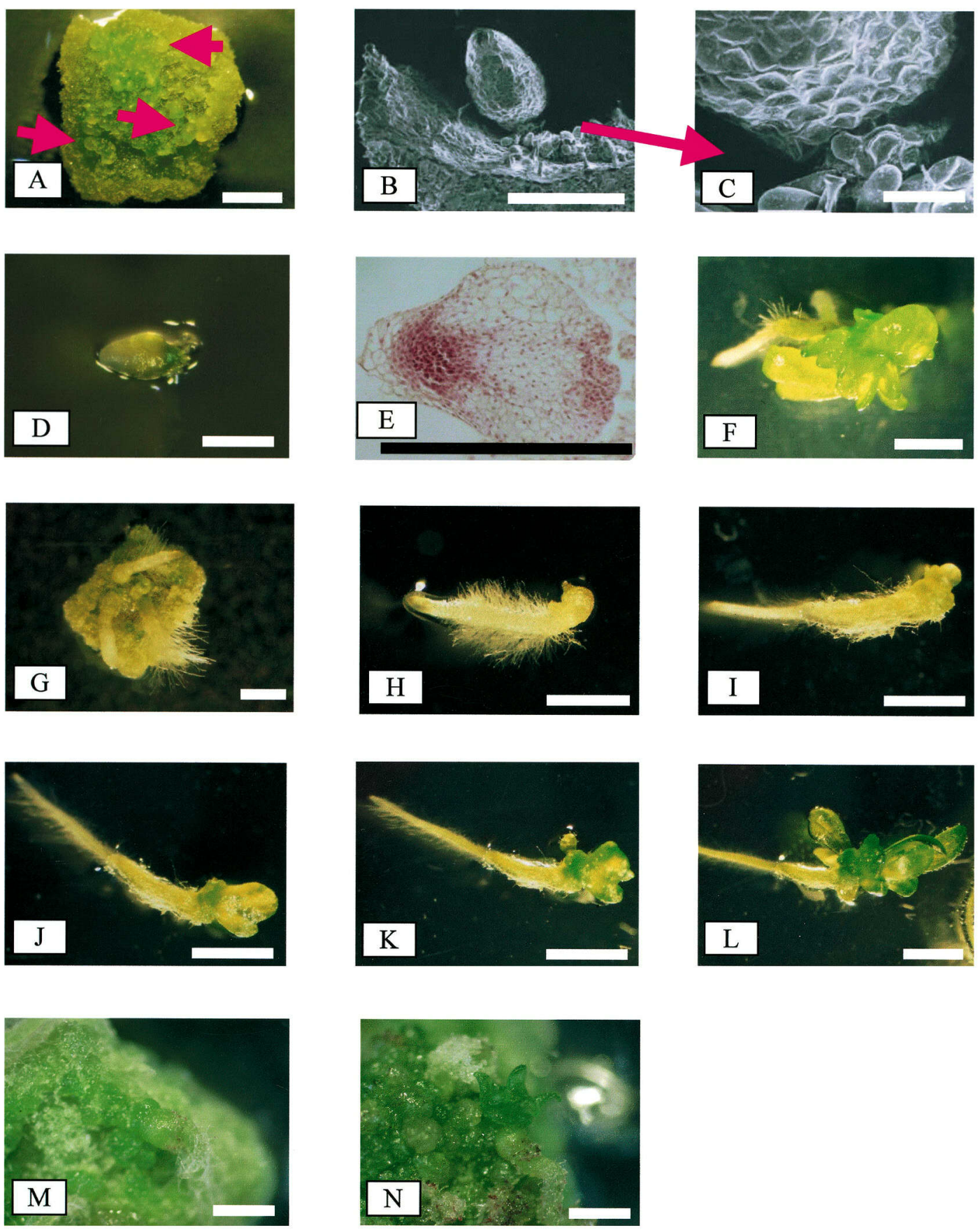

Fig. 1 Somatic embryogenesis and plant regeneration in chrysanthemum cv. Shuho-no-chikara. A ; The leaf segment on the D2K1 medium for 15 days. Arrows indicate globular-shaped somatic embryos.

B ; The globular shaped somatic embryo observed by SEM.

C ; A magnified SEM image of a part of the suspensor shown in Fig. 1B $(\times 5)$.

D ; The somatic embryo on phytohormone free MS medium for 10 days.

E; The globular shaped somatic embryo observed by histological assay.

$\mathrm{F}$; The regenerated somatic embryo on phytohormone free MS medium for 20 days.

$\mathrm{G}$; The somatic embryo on the D2K1 medium.

$\mathrm{H}$; Transferred to phytohormone free MS medium for 3 days, I ; 5 days, $\mathrm{J}$; 7 days, $\mathrm{K}$; 20 days, and $\mathrm{L}$; 30 days.

$\mathrm{M}$; The somatic embryo on the D2K1 medium for 40 days and $\mathrm{N}$; for 50 days.

Scale bar indicates $10 \mathrm{~mm}$ at $\mathrm{A}, \mathrm{G}, \mathrm{H}, \mathrm{I}, \mathrm{J}, \mathrm{K}$ and $\mathrm{L}, 0.2 \mathrm{~mm}$ at C. Those in other pictures are $2 \mathrm{~mm}$. 
Table 2 Effects of developmental stages on the frequency of somatic embryos conversion to plant of chrysanthemum cv. Shuho-no-chikara.

\begin{tabular}{lccc}
\hline Root length $^{1)}(\mathrm{mm})$ & No. of somatic embryos & No. of regenerated plants & Frequency of conversion (\%) \\
\hline 0 (globular) & 50 & 18 & 36.0 \\
$1-2$ (oval) & 50 & 48 & 96.0 \\
$3-6$ & 50 & 27 & 54.0 \\
$7-10$ & 50 & 3 & 6.0 \\
$11-15$ & 50 & 4 & 8.0 \\
$16-20$ & 50 & 2 & 4.0 \\
$>20$ & 50 & 1 & 2.0 \\
\hline
\end{tabular}

1) Root length of somatic embryos at the time when transferred to phty tohormone free MS medium.

When the somatic embryos were kept on the D2K1 medium without being transferred to phytohormone-free MS medium, the number of somatic embryos, that of regenerated plants and the frequency of conversion was 50,1 and $2.0(\%)$, respectively.

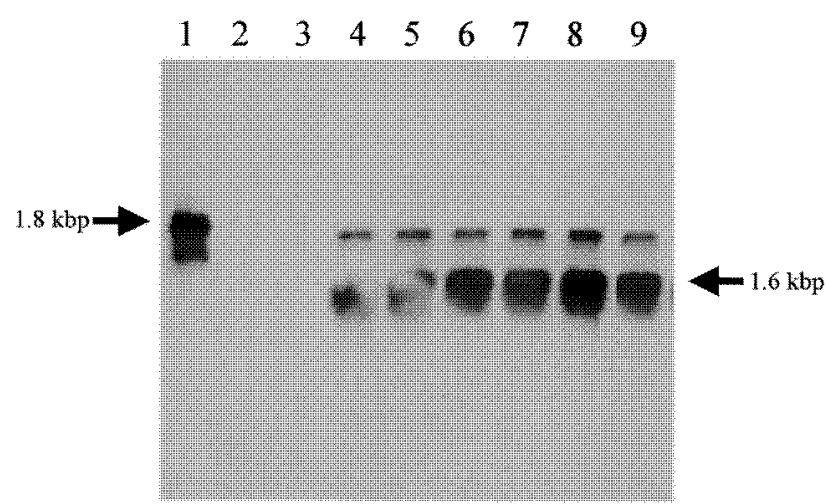

Fig. 2 Comparison of ECP63 genes expression in somatic embryos of chrysanthemum by Northern blot analysis. Total RNA was isolated from somatic embryos and other tissues, and approximately $20 \mu \mathrm{g}$ total RNA was applied in each lane. The probe was the 520 bp specific fragment of carrot embryogenic cell protein 63 (ECP63) gene.

Lane 1: pGEM-t easy-Carrot ECP63.

Lane 2: Leaves of 'Shuho-no-chikara'.

Lane 3: Petals of 'Shuho-no-chikara'.

Lane 4: Zygotic embryos of 'Shuho-no-chikara' $x$ 'Yamate-shiro'.

Lane 5:Somatic embryos of 'Shuho-no-chikara'.

Lane 6: Somatic embrvos of Monroe.

Lane 7: Somatic embryos of Symbol.

Lane 8: Somatic embryos of Kin-fusya.

Lane 9: Somatic embryos of Hiroshima-beni.

embryos produced two bands (1.6 and $1.8 \mathrm{kbp}$ ), indicating that the organs of interest were somatic embryos. By contrast, ECP63 gene expression was not observed in leaves or petals.

\section{Growth habitat of regenerated plants in a greenhouse}

Regenerated plants developed from somatic embryos of chrysanthemum were cultivated in a green- house at $25^{\circ} \mathrm{C}$ to flowering (for up to 60 days). Then the stem length, number of leaves, diameter of the flowers and time to flowering were determined. Plants propagated by cutting, as reported else where (May and Trigiano, 1991), were used as the control. The results are summarized in Table 3. The stem lengths of lines $\mathrm{SE}-3,4,14,19,20$, and 24 from somatic embryos were significantly shorter than those of controls. The numbers of leaves and flower diameters of regenerated plants and controls were similar. The time to flowering of regenerated plants differed greatly from that of controls, being shorter than controls in lines SE-2, 6, and 8, and longer in lines SE-4, 14, and 24. The SE-1 and 7 were developed poorly and died before flowering.

\section{Genetic influence on somatic embryogenesis}

To verify the applicability of the established protocol (see Fig. 3) to other chrysanthemum cultivars, somatic embryogenesis was studied in 12 popular commercial cultivars and was observed in 7 out of the 12 (Table 4). ECP63 gene expression in the somatic embryos was tested at the oval stage by Northern blot analysis, and all of them expressed ECP63 gene (Fig. 2). From 0.7 to 72.0 somatic embryos were formed on a leaf segment, and two cultivars ('Monroe' and 'Kin-fusya') produced more embryos than 'Shuho-no-chikara' did. The highest frequency of conversion of embryos to plantlets was obtained in 'Kin-fusya'. No somatic embryos were obtained with 'Pinky', 'Bingo', 'Rosanna', 'Swan' and 'Peach'. Reason for this is still nuclear. 
Table 3 The growth of regenerated plants via somatic embryogenesis of cv. Shuho-no-chikara in greenhouse

\begin{tabular}{|c|c|c|c|c|}
\hline Lines & Stem length $(\mathrm{cm})$ & No. of leaves & Diameter of flower (mm) & Days to flowering (days) \\
\hline $\mathrm{SE}-1$ & - & - & - & - \\
\hline$S E-2$ & $92.5 \pm 0.3$ & $42.1 \pm 0.2$ & $83.0 \pm 0.2$ & $64.0 \pm 0.2 *$ \\
\hline $\mathrm{SE}-3$ & $68.0 \pm 1.5 *$ & $55.0 \pm 0.1$ & $85.0 \pm 0.1$ & $66.0 \pm 0.1$ \\
\hline $\mathrm{SE}-4$ & $78.4 \pm 1.4 *$ & $44.9 \pm 0.6$ & $86.0 \pm 0.6$ & $88.0 \pm 0.6^{*}$ \\
\hline$S E-5$ & $82.7 \pm 2.2$ & $35.2 \pm 0.3$ & $79.0 \pm 0.3$ & $66.0 \pm 0.3$ \\
\hline $\mathrm{SE}-6$ & $85.2 \pm 3.1$ & $36.2 \pm 0.3$ & $88.0 \pm 0.3$ & $64.0 \pm 0.3^{*}$ \\
\hline$S E-7$ & - & - & - & - \\
\hline $\mathrm{SE}-8$ & $87.5 \pm 0.9$ & $38.5 \pm 0.1$ & $86.0 \pm 0.1$ & $62.0 \pm 0.1 *$ \\
\hline $\mathrm{SE}-9$ & $90.4 \pm 0.3$ & $38.5 \pm 0.6$ & $87.0 \pm 0.6$ & $66.0 \pm 06$ \\
\hline$S E-10$ & $87.3 \pm 2.2$ & $38.1 \pm 1.1$ & $84.0 \pm 1.1$ & $69.0 \pm 1.1$ \\
\hline $\mathrm{SE}-11$ & $94.0 \pm 2.6$ & $38.9 \pm 1.3$ & $86.0 \pm 1.3$ & $69.0 \pm 1.3$ \\
\hline$S E-12$ & $97.6 \pm 1.6$ & $37.3 \pm 0.5$ & $85.0 \pm 0.5$ & $66.0 \pm 0.5$ \\
\hline$S E-13$ & $86.5 \pm 2.5$ & $39.0 \pm 0.5$ & $88.0 \pm 0.5$ & $72.0 \pm 0.5$ \\
\hline $\mathrm{SE}-14$ & $75.5 \pm 1.4 *$ & $48.0 \pm 0.3$ & $89.0 \pm 0.3$ & $85.0 \pm 0.3^{*}$ \\
\hline$S E-15$ & $80.8 \pm 2.2$ & $36.7 \pm 0.6$ & $90.0 \pm 0.6$ & $73.0 \pm 0.6$ \\
\hline$S E-16$ & $82.7 \pm 1.6$ & $36.9 \pm 0.9$ & $89.0 \pm 0.9$ & $74.0 \pm 0.9$ \\
\hline $\mathrm{SE}-17$ & $85.1 \pm 1.8$ & $36.4 \pm 0.9$ & $86.0 \pm 0.9$ & $72.0 \pm 0.9$ \\
\hline $\mathrm{SE}-18$ & $82.0 \pm 0.6$ & $34.0 \pm 1.5$ & $85.0 \pm 1.5$ & $68.0 \pm 1.5$ \\
\hline $\mathrm{SE}-19$ & $79.5 \pm 1.2^{*}$ & $35.0 \pm 1.3$ & $89.0 \pm 1.3$ & $73.0 \pm 1.3$ \\
\hline$S E-20$ & $80.0 \pm 2.2 *$ & $35.5 \pm 0.7$ & $88.0 \pm 0.7$ & $80.0 \pm 0.7$ \\
\hline$S E-21$ & $83.2 \pm 2.2$ & $36.6 \pm 0.4$ & $87.0 \pm 0.4$ & $74.0 \pm 0.4$ \\
\hline $\mathrm{SE}-22$ & $103.6 \pm 0.6$ & $40.3 \pm 0.7$ & $88.0 \pm 0.7$ & $65.0 \pm 0.7$ \\
\hline$S E-23$ & $81.0 \pm 1.6$ & $36.4 \pm 0.2$ & $89.0 \pm 0.2$ & $77.0 \pm 0.2$ \\
\hline$S E-24$ & $79.3 \pm 1.3^{*}$ & $46.0 \pm 0.1$ & $92.0 \pm 0.1$ & $95.0 \pm 0.1^{*}$ \\
\hline Cutting & $99.3 \pm 1.6$ & $40.3 \pm 0.9$ & $91.0 \pm 0.9$ & $73.0 \pm 0.9$ \\
\hline
\end{tabular}

$\mathrm{SE}$; means somatic embryo

Data represent mean $\pm S E$ of 20 samples.

* Significant at the $5 \%$ level against the cutting of 'Shuho-no-chikara' .

\section{Discussion}

We established a method for somatic embryogenesis and plant regeneration from chrysanthemum that is simpler and more efficient than previous methods (May and Trigiano, 1991; Pavingerova et al., 1994), and is somewhat independent of cultivar. As summarized in Fig. 3, our protocol requires only two subculturing steps, two kinds of media and a constant light condition for plantlet regeneration via somatic embryogenesis. In contrast, the protocol reported by May and Trigiano (1991) requires complicated procedures, such as changes in the sucrose concentration depending on the cultivar and altering the light/dark conditions for plantlet regeneration. Their protocol was applicable to 5 out of 23 cultivars, whereas our protocol was applicable to 8 out of 13 cultivars. The protocol of Pavingerova et al. (1994) requires both semi-solid and liquid media, and only 3 to 5 somatic embryos formed per explant, whereas with our protocol yielded up to 72 embryos per explant. For the remaining 5 cultivars which did not form somatic embryos by our protocol, combination of phytohormones and/or other substances should be examined in the future.

In general, somatic embryos at the initial stage have a round shape. This is called the globular stage' or 'globular embryo' in somatic embryogenesis. The morphological polarity of the embryo is established when the round embryo becomes oval. Cotyledon initiation occurs at one end of the oval somatic embryo at the late globular stage, which is called 'the heart stage' or 'heart-shaped embryo'. At this stage, somatic embryos should have bipolar structures, with both shoot and root meristems. Then, the cotyledon elongates and the radicles are formed, which are called 'the torpedo stage' or 'torpedo-shaped embryo' (Xu and Bewley, 1992). In our case, the somatic embryos had a unique developmental process. The somatic embryos were round-shaped initially, and then 


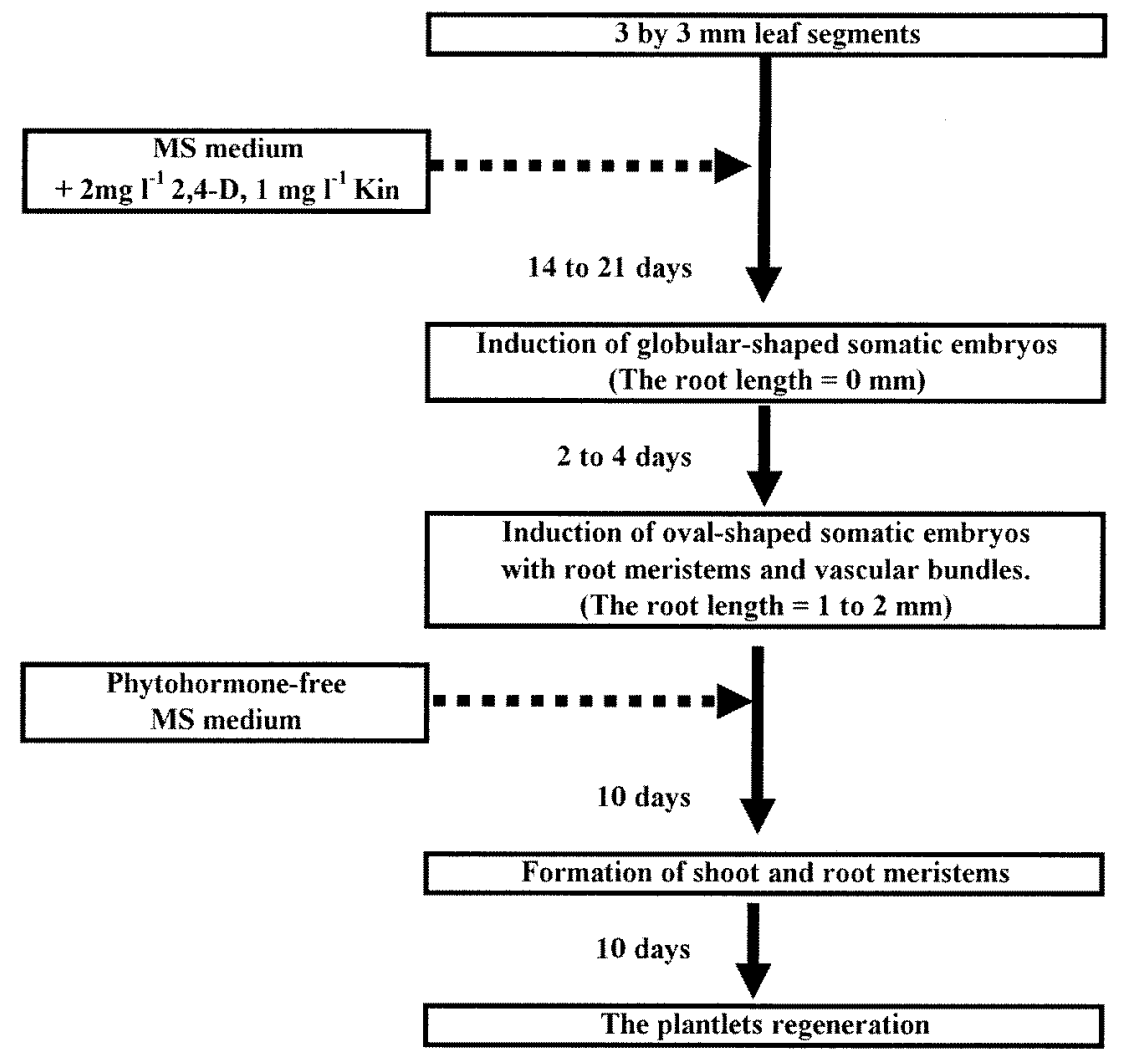

Fig. 3 Schematic illustration of the protocol for somatic embryogenesis of chrysanthemum from leaf segments.

Table 4 Effect of genotypes on somatic embryogenesis and plant regeneration in chrysathemum.

\begin{tabular}{|c|c|c|c|c|c|}
\hline Cultivars & $\begin{array}{l}\text { No. of leaf } \\
\text { segments }\end{array}$ & $\begin{array}{c}\text { No. of somatic } \\
\text { embryos }\end{array}$ & $\begin{array}{l}\text { Frequency of somatic } \\
\text { embryos per segment. }\end{array}$ & $\begin{array}{c}\text { No of regenerated } \\
\text { plants }\end{array}$ & $\begin{array}{l}\text { Frequency of } \\
\text { conversion }(\%)\end{array}$ \\
\hline Miss Betty & 18 & 23 & 1.3 & 22 & 95.7 \\
\hline Monroe & 18 & 649 & 36.1 & 640 & 98.6 \\
\hline Symbol & 18 & 20 & 1.1 & 19 & 95.0 \\
\hline Yamate-shiro & 18 & 51 & 2.8 & 48 & 94.1 \\
\hline Hiroshima-beni & 18 & 63 & 3.5 & 57 & 90.5 \\
\hline Pinky & 18 & 0 & 0.0 & - & - \\
\hline Bingo & 18 & 0 & 0.0 & - & - \\
\hline Kin-fusya & 18 & 1296 & 72.0 & 1280 & 98.8 \\
\hline Rocky & 18 & 13 & 0.7 & 10 & 76.9 \\
\hline Rosanna & 18 & 0 & 0.0 & - & - \\
\hline Swan & 18 & 0 & 0.0 & - & - \\
\hline Peach & 18 & 0 & 0.0 & - & - \\
\hline Shuho-no-chikara & 18 & 381 & 21.2 & 371 & 97.4 \\
\hline
\end{tabular}

1) Nine leaf segments were put onto each Petri dish.

roots formed from the apex of the globular somatic embryo. Shoot meristems formed on the somatic embryos after being transferred onto phytohormone - free MS medium. At this stage, our somatic embryos had bipolar structures. Northern blot analysis confirmed the expression of the embryo-specific protein (ECP63) gene in our somatic embryos, as in zygotic embryos, suggesting that the plantlet regen- eration observed in our study was embryogenesis.

A low frequency of plant regeneration is the most serious problem in somatic embryogenesis (Hanning and Conger, 1986; Parrott et al., 1989; Trigiano et al., 1989; May and Trigiano, 1991; Pavingerova et al., 1994). We examined the plant regeneration of somatic embryos at several developmental stages and discovered that the root length of the somatic 
embryo before subculturing influences the subsequent frequency of plant regeneration. Oval somatic embryos with 1 - to $2-\mathrm{mm}$ roots regenerated significantly more frequent than those at other stages, and more frequently than previously reported values (May and Trigiano, 1991; Pavingerova et al., 1994).

Somatic embryogenesis is highly dependent on genotype, as shown in other species (Hanning and Conger, 1986; Parrott et al., 1989; Trigiano et al., 1989). In previous studies on chrysanthemum (May and Trigiano, 1991), the ability to form somatic embryos from leaf segments was limited to about one-half of the cultivars evaluated, indicating genotype dependency. By contrast, our method was applicable to 8 out of 13 chrysanthemum cultivars, indicating lower genotype dependency. This method should be useful for recovering unique genotypes generated by mutation or genetic engineering techniques in chrysanthemum.

\section{Acknowledgments}

We thank Drs. E. Maeda (Nagoya University), K. Wakasa (National Institute of Crop Science), $\mathrm{H}$. Kamada (University of Tsukuba), and H. Ezura (University of Tsukuba) for their valuable comments and critical reading of the manuscript. We are grateful to Drs. S. Ohki (Fukui Prefectural University), and J. Nagatomo (The Wakasa-wan Energy Research Center) and to Mr. M. Hatashita (The Wakasa-wan Energy Research Center) for their valuable advice and help with the histological assay and SEM, and to Dr. A. Kikuchi (University of Tsukuba) for technical advice regarding the Northern blot analysis.

\section{References}

Ahmed, H. A., Andrea, M., 1987. Effect of heat treatment on acceleration chrysanthemum multiplication by meristem - tip culture. Acta Hort., 212: 99-106.

Ammirato, P. V., Styer, D. J., 1985. Strategies for largescale manipulation of somatic embryos in suspension culture. In: Zaitlin, M. et al. (Eds.): Biotechnology in plant science, pp. 161-178. Academic Press, New York, USA.

Broertjes, C., Roest, S., Bokelmann, G. S., 1976. Mutation breeding of Chrysanthemum morifolium Ram. using in vivo and in vitro adventitious bud techniques. Euphytica, 25: $11-19$.

Dalsou, V., Short, K. C., 1987. Selection for sodium chloride tolerance in chrysanthemums. Acta Hort., 212: 737740.

De Garcia, E., Martinez, S., 1995. Somatic embryogenesis in Solanum tuberosum L. cv. Désirée from stem nodal sections. J. Plant Physiol., 145: 526-530.

De Jong, J., Custers, J. B. M., 1986. Induced changes in growth and flowering of chrysanthemum after irradi- ation and in vitro culture of pedicels and petal epidermis. Euphytica, 35: 137-148.

Earle, E. D., Langhans, R. W., 1974. Propagation of Chrysanthemum in vitro. I. Multiple plantlets from shoot tips and the establishment of tissue cultures. J. Am. Soc. Hort. Sci., 99: 128-132.

Frey, L., Saranga, Y., Janick, J., 1992. Somatic embryogenesis in carnation. Hort. Sci., 27: 63-65.

Hanning, G. E., Conger, B. V., 1986. Factors influencing somatic embryogenesis from cultured leaf segments of Dactylis glomerata. J. Plant Physiol., 123: 23-29.

Hill, G. P., 1968. Shoot formation in tissue cultures of Chrysanthemum 'Bronze Pride'. Physiol. Plant., 21: 386 $-389$.

Horst, R. K., 1990. Chrysanthemum. In: Ammirato, P. V. et al. (Eds.): Handbook of plant cell culture. Vol. 5. pp. 319-336. Ornamental species, McGraw-Hill, New York, USA.

Huitema, J. B. M., Gussennoven, G. C., De Jong, J., Dons, J. J. M., 1987. Selection and in vitro characterization of low-temperature tolerant mutants of Chrysanthemum morifolium Ramat. Acta Hort., 197: 89-96.

lizuka, M., Matsumoto, E., Doi, A., Madrigal, R., Fukushima, A., 1973. Tubular floret culture of chrysanthemum and cineraria in vitro. Jpn. J. Genet., 48: $79-$ 87.

Kamada, H., Kobayashi, K., Harada, H., 1989. Stress-induced somatic embryogenesis in carrot and its application to synthetic seed production in vitro Cell Dev. Biol., 25: 1163-1166.

Kamada, H., Ishikawa, K., Saga, H., Harada, H., 1993. Induction of somatic embryogenesis in carrot by osmotic stress. Plant Tissue Cul. Lett., 10: 33-37.

Kamada, H., Tachikawa, Y., Satou, T., Harada, H., 1994. Heat stress induction of carrot somatic embryogenesis. Plant Tissue Cul. Lett., 11: 229-232.

Kato, H., Takeuchi, M., 1966. Embryogenesis from the epidermal cells of carrot hypocotyls. Sci. Pap. Coll. Gen. Educ., Univ. Tokyo, 16: 245-254.

Khalid, N., Davey, M. R., Power, J. B., 1989. An assessment of somaclonal variation in Chrysanthemum morifolium: the generation of plants of potential commercial value. Sci. Hort., 38: $287-294$.

Kiyosue, T., Kamada, H., Harada, H., 1989. Induction of somatic embryogenesis by salt stress in carrot. Plant Tissue Cul. Lett., 6: 162-164.

Kiyosue, T., Takano, K., Kamada, H., Harada, H., 1990. Induction of embryogenesis on carrot by heavy metal ions. Can. J. Bot., 68: 2301-2303.

Krasnyanski, S., Menczel, L., 1993. Somatic embryogenesis and plant regeneration from hypocotyl protoplasts of sunflower (Helianthus annuus L.). Plant Cell Rep., 12: 260-263.

Lou, H., Kako, S., 1995. Effect of auxin combinations on somatic embryogenesis in Cucumis sativus L. J. Jpn. Soc. Hort. Sci., 64: 571- 579.

Lutz, J. D., Wong, J. R., Rowe, J., Tricoli, D. M., Lawrence, Jr., R. H., 1984. Somatic embryogenesis for mass cloning of crop plants. In: Henke, R. R. et al. (Eds.): 
Tissue culture for forestry and agriculture, pp. 105116. Plenum, New York, USA.

May, R. A., Trigiano, R. N., 1991. Somatic embryogenesis and plant regeneration from leaves of Dendranthema grandiflora. J. Am. Soc. Hort. Sci., 116: 366-371.

Murashige, T., Skoog, F, 1962. A revised medium for rapid growth and bioassay with tobacco tissue cultures. Physiol. Plant., 15: 473-497.

Nakamura, T., Taniguchi, T., Maeda, E., 1994. Cyto-histological studies on somatic embryos of coffee: ultrastructural aspects. Jpn. J. Crop Sci., 63: 144- 157.

Newman, T. C., Ohme-Takagi, M., Taylor, C. B., Green, P. J., 1993. DST sequences, highly conserved among plant SAUR genes, target reporter transcripts for rapid decay in tobacco. Plant Cell, 5: 701-714.

Nomura, K., Komamine, A., 1985. Identification and isolation of single cells that produce somatic embryos at a high frequency in carrot suspension cultures. Plant Physiol., 79: 988-991.

Parrott, W. A., Williams, E. G., Hildebrand, D. F., Collins, G. B., 1989. Effect of genotype on somatic embryogenesis from immature cotyledons of soybean. Plant Cell, Tissue Organ Cult., 16: 15-20.

Pavingerova, D., Dostal, J., Biskova, R., Benetka, V., 1994. Somatic embryogenesis and Agrobacterium-mediated transformation of chrysanthemum. Plant Sci., 97: 95101.

Preil, W., Engelhardt, M., Walther, F., 1983. Breeding of low temperature tolerant poinsettia (Euphorbia pulcherrima) and chrysanthemum by means of mutation induction in in vitro culture. Acta Hort., 131: 345-351.

Reinert, J., 1958. Untersuchungen über die Morphogenese an
Gewebekulturen. Ber. Dtsch. Bot. Ges., 71: 15.

Sharp, W. R., Evans, D. A., Sondahl, M. R., 1982. Application of somatic embryogenesis to crop improvement. In: Fujiwara, A. (Ed.): Proc. 5th Intl. Congr. pp. 759762. Plant Tissue Cell Cult.

Southern, E. M., 1975. Detection of specific sequences among DNA fragments separated by gel electrophoresis. J. Mol. Biol., 98: 503-517.

Steward, F. C., Mapes, M. O., Mears, K., 1958. Growth and organized development of culture cells. II. Organization in cultures grown from freely suspended cells. Am. J. Bot., 45: 705-708.

Tabei, Y., Kanno, T., Nishio, T., 1991. Regulation of organogenesis and somatic embryogenesis by auxin in melon, Cucumis melo L. Plant Cell Rep., 10: 225-229.

Trigiano, R. N., Beaty, R. M., Dietrich, J. T., 1989. Somatic embryogenesis and plantlet regeneration in Cornus florida. Plant Cell Rep., 8: 270-273.

$\mathrm{Xu}$, N., Bewley, J. D., 1992. Contrasting pattern of somatic and zygotic embryo development in alfalfa (Medicago sativa L.) as revealed by scanning electron microscopy. Plant Cell Rep., 11: 279-284.

Zimmerman, J. L., 1993. Somatic embryogenesis: A model for early development in higher plants. Plant Cell, 5: $1411-1423$.

Zhu, C.-F., Saitou, T., Shiota, H., Kamada, H., Harada, H., 1996. cDNA cloning of ECP63, an embryogenic-cell protein from carrot (Daucus carota L.), and its expression during somatic and zygotic embryogenesis. In: $\mathrm{Xu}$, Z. - H. and Chen, Z.-H. (Eds.): Proc. 2nd Asia-Pacific Conf. pp. 144-152. Plant Cell Tissue Cult. 